\title{
Ghana's Minerals Development Fund Act: Addressing the Needs of Mining Communities
}

\author{
Journal of Energy \& Natural Resources Law, in press
}

Päivi Lujala, Geography Research Unit, PL 8000, FI-90014 University of Oulu, Finland. Email: Paivi.Lujala@oulu.fi

John Narh*, Department of Geography, NO-7491, Norwegian University of Science and Technology, Norway. Email: jnacademics@gmail.com.

* Corresponding author

\section{Acknowledgements}

We are grateful to Kendra Dupuy and the participants of the $5^{\text {th }}$ School of Social Sciences International Conference at the University of Ghana for their useful comments and suggestions on the earlier versions of this article and the Minerals Development Fund Secretariat for granting us an interview.

\section{Funding}

This work was supported by the Academy of Finland under Grant numbers 314143 and 309206.

\begin{abstract}
Despite a large mining sector and a well-structured mineral revenue distribution system, mining communities are among the poorest in Ghana. To promote socio-economic development in the mining communities, in 2016, the Parliament of Ghana passed the Minerals Development Fund Act. This article examines the Act's potential in addressing existing challenges in the allocation and utilisation of mineral royalties in Ghana and its potential in promoting development in Ghana's mining communities. It shows that the Act missed the opportunity to address misuse of mineral royalties and to encourage local participation and increase transparency and accountability in mineral royalty management.
\end{abstract}

Keywords: Act 912, accountability, development, Ghana, mining, mineral royalty distribution, revenue capture, transparency. 


\section{Introduction}

Ghana is endowed with gold, diamonds, bauxite, manganese, salt, limestone, granite and oil, and its mining and quarrying sector contributes significantly to its economy. Ghana is the second largest gold producer in Africa after South Africa and the tenth largest producer in the world. ${ }^{1}$ Gold, the flagship mineral, contributed 96 per cent of mineral export revenues (excluding oil and gas) ${ }^{2}$ and earned Ghana over US\$ 5,700 million in $2017 .^{3}$ The mining sector contributed 43 per cent of total export revenues and earned Ghana approximately US\$230 million in corporate income taxes and US\$ 170 million in mineral royalties in $2017 .{ }^{4}$ The mining sector received more than US\$12,000 million in total investments during the period from 2000 to $2016 . .^{5}$ The large-scale mining sector provides approximately 15,000 jobs and supports employment for an additional 65,000 people. ${ }^{6}$ It is estimated that the mining and quarrying sector provides jobs for over 250,000 regular and casual workers as well as individuals who work for family enterprises. ${ }^{7}$

While mining is an integral part of Ghana's economy and export sector, its mining communities are generally poor. Mining imposes socio-economic costs on host communities through land acquisition, environmental degradation, pollution and a high cost of living. ${ }^{8}$ Although the host communities are entitled to different types of compensation and mineral royalty transfers, they are still among the poorest communities in Ghana. ${ }^{9}$ One reason for this is the inadequate, one-time compensation for land when it is appropriated for mining

1 O'Connell R et al, GFMS Gold Survey 2018 (London, UK: Thomson Reuters 2018) 21.

2 Offshore oil and gas production is another major revenue source for Ghana and accounted for 6 per cent of the total government revenues and 23 per cent of export revenues in 2017. Oil and gas revenues are distributed and spent according the Petroleum Revenue Management Act.

3 Ghana Chamber of Mines, Performance of the Mining Industry in 2017 (GCM 2018) 9-11 (ghanachamberofmines.org/wp-content/uploads/2016/11/Performance-of-the-Industry-2017.pdf).

4 Ibid.

5 Ghana Chamber of Mines, Factoid on the Industry's Performance (GCM 2016) 26-27 (https://ghanachamberofmines.org/wp-content/uploads/2016/11/Factoid-2016.pdf) .

6 Ghana Chamber of Mines (n 3 above) 14; International Council on Mining and Minerals 'Mining in GhanaWhat Future Can We Expect (UK: ICMM 2015) 38.

7 Ghana Statistical Service, 2015 Labour Force Report (Ghana: GSS 2016) 129.

8 Aboka EY, Cobbina SJ and Dzigbodi DA, 'Review of Environmental and Health Impacts of Mining in Ghana' (2018) 8(17) Journal of Health and Pollution 45-49; Aragón FM and Rud JP, 'Polluting Industries and Agricultural Productivity: Evidence from Mining in Ghana' (2016) 126 The Economic Journal 2000; Tenkorang EY and Osei-Kufuor P, 'The Impact of Gold Mining on Local Farming Communities in Ghana' (2014) 8(1) Journal of Global Initiatives: Policy, Pedagogy, Perspective 36.

9 Dupuy KE 'Corruption and Elite Capture of Mining Community Development Funds in Ghana and Sierra Leone' In A Williams and P Le Billon (Eds.), Corruption, Natural Resources and Development: From Resource Curse to Political Ecology (UK \& USA: Edward Elgar Publishing Limited 2017) 73. 
purposes; ${ }^{10}$ however, another important reason is the local authorities' capture of mineral royalties transferred back to the mining areas. ${ }^{11}$

In March 2016, to improve the governance of mineral royalties assigned to benefit the communities and institutions responsible for the development of mining, the Parliament of Ghana enacted the Minerals Development Fund Act (Act 912). ${ }^{12}$ Act 912 (henceforth, the Act) provides financial resources to the mining communities and affected landowners as well as to traditional authorities and district assemblies in areas that host extractive industries. ${ }^{13}$ The Act also provides financial resources for mining sector development and research and to the Ministry of Lands and Natural Resources (MLNR) to support and develop its policy planning, evaluation and monitoring functions with respect to mining. ${ }^{14}$

This article examines the ability of the Act to resolve the challenges related to mineral royalty spending and the promotion of socio-economic development in the mining communities. Based on the provisions of the Act, we argue that while it provides a new approach to promote socio-economic development in the mining communities, it does not address the existing problems of the fundamental linguistic ambiguity in the Constitution of Ghana that has contributed to corruption and royalty capture at the local level and delays in disbursements to the Minerals Development Fund (MDF). Further, the new approach used to promote development in the mining communities is inadequately funded and lacks effective mechanisms to enhance transparency and accountability.

The rest of the article is structured as follows. Section 2 describes the administrative structure of Ghana and how the central government collects and distributes mineral royalties. Section 3 discusses the shortcomings of the pre-Act system with a focus on the misappropriation of mineral royalties that are transferred to mining areas. Section 4 presents the key aspects of the Act with a focus on the royalty transfers to and spending in mining areas. Section 5 assesses

10 Akabzaa TM 'Mining in Ghana: Implications for National Economic Development and Poverty Reduction' In B Campbell (Ed.), In Mining in Africa: Regulation and Development (London: Pluto Press/IDRC 2009) 58; Twerefou DK, Tutu K, Owusu-Afriyie J and Adjei-Mantey K 'Attitudes of Local People to Mining Policies and Interventions' E-33107-GHA-1 (International Growth Centre 2015) 24 and 49.

11 Dupuy (n 9 above) 72-73; International Council on Mining and Metals (ICMM), Ghana Country Case Study: The Challenge of Mineral Wealth: Using Resource Endowments to Foster Sustainable Development (London, UK: ICMM 2007) 77-78; Standing A, 'Ghana's Extractive Industries and Community Benefit Sharing: The Case for Cash Transfers' (2014) 40 Resources Policy 76-77. doi:http://dx.doi.org/10.1016/j.resourpol.2014.03.003.

12 Parliament of Ghana, Minerals Development Fund Act, 2016, Act 912 (Accra: Republic of Ghana 2016)

13 Act 912, 2(a-c) and 5(a,b).

14 Act 912, 2(d) and 5(c-e). 
the ability of the Act to alleviate poverty in the mining communities and provides a basis to improve mining royalty management. Section 6 provides recommendations, and Section 7 presents concluding remarks.

\section{Administrative structure of Ghana and mineral royalty distribution system}

\section{Administrative structure}

Ghana is divided into ten administrative regions. For each region, the President appoints a Regional Minister to represent him. Districts are the second-level administrative units and are governed by district assemblies. The President appoints a chief executive (a role similar to city mayor in many countries) for each district. The district assembly consists of the appointed district chief executive, one person from each electoral area within the district who is elected by universal adult suffrage, the member or members of Parliament from the constituencies that fall within the district and other members appointed by the President (up to 30 per cent of the assembly can be appointed by the President). In 2019, Ghana had 260 districts.

The Electoral Commission of Ghana tries (but has not always been successful) to create district boundaries that conform to the boundaries of traditional areas. A traditional area is a geographical area dominated by or believed to be a territory of people with the same ethnic background. Ghana has 263 traditional areas. ${ }^{15}$ Each traditional area is headed by a paramount chief. Each town in the traditional area is headed by a divisional chief, and each community is headed by a sub-chief. Chieftaincy is hereditary; however, the selection of a chief is 'by a culturally-sanctioned means of popular approval'. ${ }^{16}$ Each traditional area has a traditional council that consists of the paramount chief and selected divisional chiefs. The paramount chief appoints the other traditional council members; however, the appointment must be approved by the Council of Elders that consists of elders of the various extended families or lineages living in the traditional area and the chief's fetish priest. ${ }^{17}$

15 Owusu-Mensah I, 'Politics, Chieftaincy and Customary Law in Ghana's Fourth Republic' (2014) 6(7) The Journal of Pan African Studies 273.

16 Panyin OAO, 'Chiefs and Traditional Authorities and Their Role in the Democratic Order and Governance' Constitutional Review Series 9 (Accra, Ghana:Institute of Economic Affairs 2010) 2

17 The main tasks of the traditional councils are to settle disputes and help maintain peace in the traditional area; organise festivals and durbars; launch development projects using the donations and royalties they receive; lobby the central government for assistance with developmental projects and, in mining areas, grant 
The paramount chief is the custodian of the customary land. Customary land is a type of land that collectively belongs to an ethnic group. ${ }^{18}$ The paramount chief holds the land in trust on behalf of and for the benefit of the ethnic group. ${ }^{19}$ Such lands are called stool or skin lands.

Stool and skin relate to the paramount chiefs' symbol of power. In southern Ghana, the seat of a paramount chief that represents the power, and sometimes doubles as the emblem of the ethnic group, is a stool carved from wood or made from precious metal. In northern Ghana, the seat of a chief is usually an animal skin. The stool or skin thus represents a specific ethnic group. Only one person (the paramount chief) can occupy the stool or the skin and have the allodial title for the stool or skin land. ${ }^{20}$

\section{Minerals royalty distribution system}

Ghana has a well-defined formula for distributing mining revenues (Figure 1). Generally, mining companies pay 5 per cent of their total revenue as a mineral royalty to the central government through the Ghana Revenue Authority (GRA). The central government retains 80 per cent of the mineral royalty in the Consolidated Fund (CF) and transfers the rest to the MDF. $^{21}$ The MDF is a fund created to, among other things, receive and disburse mineral royalties to mining institutions and local authorities. The MDF retains half of what it receives (10 per cent of total mineral royalties) and transfers the remaining 10 per cent to the Office of the Administrator of Stool Lands (OASL). ${ }^{22}$

permission to mining companies to operate in the traditional area. See Campion BB \& Acheampong E, 'The Chieftaincy Institution in Ghana: Causers and Arbitrators of Conflicts in Industrial Jatropha Investments' (2014) 6 Sustainability 6338; Dawda TD, 'Challenges of the Collaboration between Formal Local Government Actors and the Chieftaincy Institution in Ghana: Lessons from the Sissala East District of the Upper West Region of Ghana' (2013) 3(12) International Journal of Humanities and Social Science 240.

18 Another type of customary ownership is family land, which is land that belongs to an extended family.

19 Agidee Y, Forest Carbon in Ghana: Spotlight on Community Resource Management Areas (Washington, DC: Forest Trends, Katoomba Group's Legal Initiative Country Study Series 2011) 8.

20 Mahama C and Baffour O, 'Management of Stool Land Revenue in Ghana: A Study of the Nkawie and Toase Stools of the Atwima Nwabiagya District of the Ashanti Region' (2009) 29(1) Journal of Science and Technology (Ghana) 28.

21 The Consolidated Fund is the public purse of Ghana to which all revenues are paid. This fund is managed by the Ministry of Finance and Economic Planning. It is important to mention that before the Act, the MDF had no separate account; thus, in practice, its 10 per cent share was also kept in the Consolidated Fund.

22 The OASL is a national institution mandated by the Constitution of Ghana, Section 267(2) and the Stool Lands ACT 481 of 1994 to collect and distribute stool land revenues. The OASL has offices in seven of the ten administrative regions and over 90 district offices. The district offices receive revenues proportional to the revenues originating from the district. 
The OASL allocates what it receives according to Article 267 Section 6 of the 1992 Constitution of Ghana. ${ }^{23}$ The OASL keeps 10 per cent of what it receives to cover its administrative costs, and it distributes the remaining as follows: 20 per cent to the traditional authority (i.e., the paramount chief) of the area from which the revenue originates; 25 per cent to the traditional council of the mining area to maintain the stool/skin, which is received by the paramount chief on the behalf of the council; and 55 per cent to the district assembly of the mining area. ${ }^{24}$ The payments are based on revenues generated at the mine level. ${ }^{25}$

Article 267 Section 6(a) of the 1992 Constitution of Ghana stipulates 'twenty-five per cent [of stool/skin land revenues] to the stool through the traditional authority for the maintenance of the stool in keeping with its status'. As the stool/skin represents the group of people (the subjects) who are being ruled by a paramount chief, and given that stool/skin land collectively belongs to the ethnic group, traditional councils should use the 25 per cent mineral royalty assigned for the maintenance of the stool in a way that will benefit the people rather than the chiefs. ${ }^{26}$ Further, as the MDF was explicitly established to develop mining communities, the traditional authorities should priorities mining communities. ${ }^{27}$ Similarly, the district assemblies are required to use the mineral royalties they receive to advance socio-economic development in the mining communities. ${ }^{28}$ The 20 per cent received by the paramount chiefs is considered to be compensation for their services for the traditional area, and it forms part of their personal income. ${ }^{29}$

Figure 1 about here

23 Article 267 applies to all revenues generated from stool lands.

24 See the 1992 Constitution of Ghana, Section 267(6).

25 An interview with an official from the OASL's Eastern Regional Office in January 2018.

26 Opoku K, Forest Governance in Ghana: An NGO Perspective (UK: FERN 2006) 15; Standing (no 11 above) 76.

27 Standing (n 11 above) 75-77.

28 Auditor General's Report, 'Utilisation of Mining Development Fund by Metropolitan, Municipal and District Assemblies', Re No. AG.01/109/Vol.2/66 (Republic of Ghana 2013) 5; Dupuy (n 9 above); Standing (n 11 above) 75 .

29 During precolonial times, paramount chiefs were entitled to one-third of the minerals mined within their traditional areas. See Abdulai AG, 'Competitive clientelism and the political economy of mining in Ghana', Working Paper 78 (UK: ESID 2017) 32. 


\section{Challenges of the pre-Act Minerals Development Fund}

The MDF was established by an executive fiat in 1993 to redistribute mineral royalties from the central government to local institutions through the OASL and to support the development of the mining sector. ${ }^{30}$ Despite attempts of the pre-Act MDF to promote socio-economic development, the mining communities have remained poor. ${ }^{31}$ Mining-induced environmental degradation and insufficient compensation for land appropriation have exposed the mining communities to poverty. ${ }^{32}$ Land degradation in particular poses a threat to local communities' livelihoods as farming is a major economic and subsistence activity in many mining communities. Moreover, many of the alternative livelihood programmes in the mining communities have been unpopular among the local people as they are often underfunded and the livelihood opportunities they provide tend to be less lucrative than small-scale mining. ${ }^{33}$

The main reasons for the pre-Act MDF's inability to address the challenges faced by the mining communities include its lack of legal backing, delays in and inadequate payments of mineral royalties to the MDF and local authorities, insufficient funding for development projects, and the misappropriation of royalties by local authorities. These factors have contributed to putting Ghana 'very far from obtaining optimal benefits from its mining sector'. 34

\section{Lacked legal backing}

The establishment of the MDF and its functions were not stipulated by law, and until 2016, it was managed through administrative directives. ${ }^{35}$ Thus, the mineral royalties assigned to the MDF were exposed to subjective spending by the Ministry of Finance and Economic Planning (MoFEP) and mining-related institutions as there were no legal or regulative stipulations. ${ }^{36}$ During the pre-Act period, the MDF provided financial resources for research and exploration with little attention to addressing mining-related issues in the mining communities due to the

30 Adimazoya NT, 'Staying Ahead of the Curve: Meeting Ghana's Commitment to Good Governance in the Mining Sector' (2013) 31(2) Journal of Energy \& Natural Resources Law 158, doi: https://doi.org/10.1080/02646811.2013.11435326; Standing (n 11 above) 75-77.

31 Ibid.

32 Twerefou et al (n 10 above) 25 and 28.

33 Ibid, 30 and 56; Hilson G and Banchirigah SM, 'Are Alternative Livelihood Projects Alleviating Poverty in Mining Communities? Experiences from Ghana' (2009) 45(2) Journal of Development Studies 186, doi: $\underline{10.1080 / 00220380802553057}$

34 Akabzaa (n 10 above) 61.

35 Adimazoya (n 30 above) 160

36 Ibid. 
lack of legal guidance and the fact that there were no stipulations for a specific percentage of mineral royalties retained in the MDF to be spent on the mining communities. ${ }^{37}$ To address mining-related issues in the mining communities, the MDF mostly relied on ad hoc projects with the aim of minimising the environmental consequences of mining and to support alternative livelihoods. ${ }^{38}$

\section{Delayed disbursement and non-payment of mineral royalties}

Other challenges related to the pre-Act MDF were the often-delayed disbursements and nonpayment of royalties by the central government to the MDF. ${ }^{39}$ Although the mining companies pay mineral royalties quarterly, the MoFEP often failed to transfer the funds to the MDF on time as there were no stipulations on the timeline for such transfers. ${ }^{40}$ For instance, in 2016 , the mineral royalty transfers to the local authorities were in arrears by almost US\$ 30 million. ${ }^{41}$ Delays in transfers disrupt local authorities' planning and expenditure programmes as it is a challenge for district assemblies and traditional councils to rely on royalties that are not released regularly and without delays. Moreover, there have been times when the local authorities did not receive mineral royalties at all. For instance, in 2001 and 2013, the traditional councils and district assemblies did not receive mineral royalties because the MoFEP did not release funds to the MDF while the central government retained the entire MDF share. ${ }^{42}$

\section{Insufficient mineral royalties}

The amount of the mineral royalties going to local authorities was considered insufficient to address the needs of the mining communities. For example, several paramount chiefs have indicated that the mineral royalty payments they received were inadequate to contribute to meaningful socio-economic development in the mining communities. ${ }^{43}$ Some chiefs have argued that district assemblies and traditional councils can only improve development in the

37 Ibid.

38 Ministry of Lands and Natural Resources, Annual Performance Report (Ghana: MLNR 2014) 77; Standing (n 11 above) 75 .

39 ICMM (n 11 above); Morgandi M, Extractive Industries Revenues Distribution at the Sub-National Level (New York: Revenue Watch Institute 2008) 34.

40 Twerefou et al (n 10 above) 19.

41 Abdulai (n 29 above) 29; Swanzy SA “"Pay us all our Royalties” - Chiefs cry out to Finance Ministry” (2016). Retrieved on 9th September, 2019 from: http://pulse.com.gh/business/mining-pay-us-all-ourroyaltieschiefs-cry-out-to-finance-ministry-id5384719.html.

42 Twerefou et al (n 10 above) 19.

43 Abdulai (n 29 above) 29; ICMM (n 11 above); Akabzaa (n 10 above) 36. 
mining communities if the royalty share assigned to them is increased from 9 per cent to 35 per cent. The Ghana Chamber of Mines also estimated in 2016 that the mining communities would need at least 30 per cent of the total mineral royalties paid by the companies to be able to address their needs. ${ }^{44}$ Therefore, the 9 per cent share of total mineral royalties assigned to local authorities seems insufficient.

\section{Traditional authorities' capture of mineral royalties}

Another challenge of the pre-Act MDF was the traditional authorities' capture of mineral royalties assigned to the stool/skin (the 2.25 per cent share in Figure 1). ${ }^{45}$ The main underlying factor that contributed to the appropriation and misuse of mineral royalties by some paramount chiefs and traditional councils was the linguistic ambiguity of how the mineral royalties should be spent to maintain the stool. Some of the traditional councils (i.e., in practice often the paramount chiefs) misinterpreted the clause 'for the maintenance of the Stool in keeping with its status' to mean that the occupant of the stool or the skin could use the royalty received for the maintenance of the stool to finance private projects. ${ }^{46}$ Some paramount chiefs, for example, have purchased limousines and organised expensive durbars and festivals in the name of maintaining the status of the stool. The following was documented in a report by the International Council on Mining and Metals (ICMM) on the socio-economic impact of mining in Ghana:

'There is strong evidence that payments to traditional councils and stools tend to finance expenditures other than those that benefit the local communities involved. This is at least partly because of the genuine uncertainty as to the "appropriate purpose" of this share of the funds. The wording - "Stool Land revenues are to be used to maintain the stool in keeping with its status" - has been interpreted as meaning that it is legitimate to pay for regalia and the trappings of royalty - limousines, jewellery and ceremony. This interpretation is in contrast to the expectations of the subjects of the stools, who presume that these funds are to be applied primarily to development projects. $^{47}$

44 Ghana Chanber of Mines, Performance of the Mining Industry in 2016 (GCM 2017) 21. (https://ghanachamberofmines.org/wp-content/uploads/2016/11/Performance-of-the-Mining-Industry-in2016.pdf).

45 Standing (n 11 above) 76; Twerefou et al. (n 10 above) 19.

46 Ibid.

47 ICMM (n 11 above) 77-78. 
Although paramount chiefs organise festivals for and on behalf of the people, this type of expenditure hardly promotes sustainable development in the mining communities. Further, as documented, for example, by Dupuy, some mining communities are underdeveloped because the paramount chiefs have spent the mineral royalties they have received on personal projects and desires, and, in general, the paramount chiefs tend not to be accountable for the spending of mineral royalties. ${ }^{48}$ Thus, the traditional authorities' capture of royalties has deprived the mining communities of sustainable socio-economic development.

\section{District assemblies' misappropriation of mineral royalties}

The district assemblies have also misused the mineral royalties allocated to them. They have been found to have diverted district funds, which include mineral royalties, and they have destroyed receipts, invoices and expenditure documents. ${ }^{49}$ In addition, according a report by Twerefou and his colleagues, some district assemblies 'claim that they are governed by the local government laws and therefore they cannot be compelled by anyone to use the funds in a specific way such as using it to fund development activities in communities affected by mining. ${ }^{50}$ Further, the report documented that the district assemblies regarded mineral royalties as a natural resource windfall and spent the royalties without prioritising the mining communities. ${ }^{51}$ For instance, the district assemblies used mineral royalties for recurrent expenditures such as purchasing fuel for administrative vehicles, collecting and disposing waste or providing plastic chairs to the mining communities. ${ }^{52}$ In many cases, district assemblies used mineral royalties to establish developmental projects in areas (usually district capitals) far from the mining communities. ${ }^{53}$

48 Adimazoya (n 30 above) 159; Dupuy (n 9 above); Standing (n 11 above) 76.

49 Boachie-Danquah N 'Reducing Corruption at Local Government Level in Ghana' In M Alam and R Koranteng (Eds.) Decentralisation in Ghana (UK: Commonwealth Secretariat 2011) 118-121; Standing (n 11 above) 77

50 Twerefou et al (n 10 above) 19.

51 Ibid.

52 Ashiadey F, 'Improving the Impact of Mining Royalties at the Local Level in Ghana' (EITI 2014) Retrieved on 4th July, 2017 from https://eiti.org/blog/improving-impact-of-mining-royalties-at-local-level-in-ghana; Auditor General's Report (n 28 above) 13; Bloch R and Owusu G, 'Linkages in Ghana's Gold Mining Industry: Challenging the Enclave Thesis' (2012) 37(4) Resources Policy 439 doi: https://doi.org/10.1016/j.resourpol.2012.06.004.

53 Mahama and Baffour (n 20 above) 32. 


\section{The content of the Minerals Development Fund Act (Act 912)}

The Act provides the legal basis for the MDF. Although the MDF operates under the MLNR, it has a separate account and an autonomous secretariat and board. The Act mandates the President of Ghana to appoint an 11-member board to govern the MDF (the first board was inaugurated in April 2019). ${ }^{54}$ The board consists of a chairperson; the chief director of the MLNR; the chief executive director of the Minerals Commission, ${ }^{55}$ the executive secretary of the Lands Commission; ${ }^{56}$ and representatives of the Ministry of Local Government and Rural Development, the Ministry of Environment, Science, Technology and Innovation, the MoFEP, the OASL, the Ghana Chamber of Mines, traditional authorities and women. ${ }^{57}$ The term for members of the MDF board is four years, and members can serve for a maximum of two terms. ${ }^{58}$ The board meets at least once every three months. ${ }^{59}$ One of the board's responsibilities is to ensure the accountability of the distribution and spending of the mineral royalties ${ }^{60}$ and, in consultation with the Minister of Mines, to determine the criteria for disbursing and spending the royalties received by the MDF.

Although the Parliament of Ghana could have increased the amount of mineral revenues accruing to the MDF by increasing the royalty transfer percentage, the Act maintains that 20 per cent of the mineral royalties is to be transferred to the MDF. However, the Act mandates the MDF board to make recommendations regarding the royalty percentage that the mining companies pay to the central government. ${ }^{61}$

Further, with regard to direct transfers to subnational units, the Act maintains that 50 per cent of the mineral royalties transferred to the MDF should be allocated to the OASL and be 'disbursed as prescribed by law' by the OASL. ${ }^{62}$ Although the Act does not explicitly state to which 'law' this provision refers, it most likely refers to Section 267(6) of the 1992

\footnotetext{
54 Act 912, 6(2).

55 The Minerals Commission is a government agency that regulates and manages the utilization of mineral resources and coordinates and implements policies related to mining.

56 The Lands Commission is a government agency that manages public lands and makes recommendations regarding land policies in Ghana.

57 Act 912, 6(1).

58 Act $912,8(1)$.

59 Act 912, 9(1).

60 Other sources of funds that flow to the MDF are grants, gifts, donations and money approved by parliament. See Act 912, 3 .

61 Act 912, 7(j).

62 Act 912, 21(3)(a).
} 
Constitution, thus maintaining the pre-Act status quo with regard to how the OASL distributes the royalties to paramount chiefs, traditional councils and district assemblies.

Regarding the other 50 per cent of the funds received by the MDF, the Act provides a detailed distribution formula (Table 1) that differs from the former mineral royalty distribution system, which only vaguely specified that the MDF's share should be used to support mineral- and mining-related research and development and the mining communities. The MDF is required to allocate 30 per cent to support and develop the mining sector through the MLNR, the Mineral Commission, the Geological Survey Department and the MDF's own projects. A maximum of 2 per cent of the royalties is to be spent to cover the MDF's administrative expenses related to the management of the fund. ${ }^{63}$

\section{Table 1 about here}

The most remarkable feature of the Act is the establishment of the Mining Community Development Scheme (MCDS) in each mining community 'to facilitate the socio-economic development of communities in which mining activities are undertaken and that are affected by mining operations'. ${ }^{64}$ In each community, a Local Management Committee (LMC) is responsible for administering and overseeing the MCDS scheme. ${ }^{65}$ The Act dedicates 20 per cent of the MDF's royalty share to the scheme. To receive royalties under the scheme, the LMC must prepare and present a project proposal to the MDF board, which the board will review; if the project is approved, it will be financed. Each community is entitled to funding in proportion to what the mining company operating in the area contributes towards the mineral royalty that is paid to the central government through the GRA. ${ }^{66}$

According to the Act, an LMC must have at least six members, which should include the district chief executive (or his representative) from the district in which the mining area is located, traditional rulers of the mining community (the number is not stipulated in the Act), one representative from the District Minerals Commission (to be the LMC's secretary), one representative from each mining company operating in the district, one representative from a

63 Of the total funds, 2 per cent is not included in Table 1 as the act does not specify whether this 2 per cent should be deducted from the 20 per cent royalty share it receives or from the 10 per cent it retains after having distributed the OASL share. Therefore, it is not clear on what basis the MDF should calculate the share that can be spent on administrative costs (an interview with an MDF officer, June 2018).

64 Act 912, 17.

65 Act 912, 20(1).

66 Interview with an MDF officer, June 2018. 
women's group, and one representative from a youth group. ${ }^{67}$ The LMC is to be chaired by 'a person in the community appointed by the $[\mathrm{MDF}]$ board in consultation with the district assembly and traditional authorities of the mining community'. ${ }^{68}$

\section{Assessment of the Act}

\section{Potential}

One of the main objectives of the Act is to ensure that the mining communities receive their fair share of mineral royalties and that these funds are spent in such a way that promotes socioeconomic development. ${ }^{69}$ The Act's strengths with regard to mining community development lie in the establishment of the MCDS and LMCs and in the clearly specified royalty distribution formula.

The establishment of the MCDS and the associated LMCs to facilitate socio-economic development in the mining communities is a clear improvement as, unlike the district assemblies and traditional councils, which may prefer to address the development needs of the district or traditional area in general, the MCDS and LMCs are clearly mandated to fund only development projects in mining-affected communities. Thus, the Act has the potential to ensure the socio-economic development of the mining communities by limiting spending on development projects outside the mining-affected communities.

It is notable that, through the MCDS scheme, all mining communities should be able to benefit from MDF funded development projects as each mining community is to have its own LMC with an explicit entitlement to a share of the mineral royalties. This is in contrast to the preAct period when there were no legal stipulations on which the mining communities should receive MDF funded development projects and for what amount. It is also positive that the royalty spending decisions are relatively firmly anchored to the local level through the LMCs as the local committees should have a better understanding of the most pressing development needs in the mining communities. Further, the Act also clearly states the percentage to be used for the MCDS whereas, previously, the share of royalties to be spent on projects in the mining communities was left to the discretion of the MDF.

67 Act 912, 19(2).

68 Act $912,19(3)$.

69 Act 912, 2(a-c), 5(a,b) and 17. 
Another strength of the Act is the clearly specified distribution formula for mineral royalties received by the MDF. The Act is straightforward about the percentage of mineral royalties distributed to the mining institutions for research and training and for general improvement in the mining sector. ${ }^{70}$ This specification removes any doubt about the percentage of mineral royalties to which the different mining institutions are entitled and the purpose for which the money is distributed. This can make auditing easier and more targeted, which can enhance accountability in royalty spending.

\section{Challenges}

Despite the attempts and good intentions to improve living conditions in the mining areas, the Act contains stipulations that may hinder such development. First, the Act does not clarify how the portion of the royalties that is distributed to the traditional councils should be spent. Second, the mode of selecting and the composition of the LMCs can potentially expose them to cronyism and may limit local participation in decision making regarding how the mineral royalties are spent. Third, the Act missed an opportunity to mandate the GRA to transfer the 20 per cent of total mineral royalties directly to the MDF. Fourth, the percentage of mineral royalties designated to the MCDS scheme is most likely inadequate to develop the mining communities. Finally, the Act provides few mechanisms to ensure transparency and accountability in the distribution and spending of the mineral royalties. Without addressing these challenges, the MDF may not achieve its stated objective of enhancing socio-economic development in the mining communities.

\section{$\underline{\text { Linguistic ambiguity }}$}

The Act fails to address the linguistic ambiguity and shortcomings of the Constitution, which makes the use of mineral royalties at the local level susceptible to misuse. Although the linguistic ambiguity of Section 267(6) of the Constitution of Ghana on the allocation of stool land revenue is widely acknowledged to promote the chiefs' capture of the mineral royalties, ${ }^{71}$ the Act does not provide any guidance on how the Constitution's provision of 'twenty-five per cent to the stool through the traditional authority for the maintenance of the stool in keeping with its status ${ }^{72}$ should be interpreted. Further, the Act does not provide any specific stipulations on how the mineral royalties transferred to the district assemblies should be spent.

70 Act 912, 21(3)(a-f), 10-11

71 Dupuy (n 9 above); ICMM (n 11 above); Standing (n 11 above) 76.

721992 Constitution of Ghana, Section 267(6)(a). 
As such, the Act is unlikely to limit the current misuse and misappropriation of mineral royalties by local authorities.

\section{Selection of the LMC members}

The transfer of mineral royalties to districts, traditional areas and mining communities is a form of fiscal decentralisation in which the state cedes fiscal decision making to subnational units and institutions; however, its success (and that of any form of decentralisation) depends on the enhancement of local democracy and endowed communities. ${ }^{73}$ Moreover, local democracy and representation is necessary to induce participatory development that involves and empowers local community members and their representatives to influence decisions concerning them and local development. ${ }^{74}$ Such participation enables local people, including the poor and less privileged, to be heard and shift focus to the needs and priorities of the people, which can contribute to better resource royalty spending and enhance the sense of ownership of funded development initiatives. ${ }^{75}$

The Act, however, missed the opportunity to encourage participatory development in the allocation and spending of mineral royalties: the MDF's eleven-member board consists of appointees, and, in turn, the board is central in appointing the LMC members. Importantly, the Act does not firmly establish how the local community representatives should be selected, simply stating that the LMC shall include 'one representative of an identified women's group' and 'one representative of an identified youth group' ${ }^{76}$ Preferable, the Act should have sought to enhance local democracy and participation by more firmly stating that local community members should be elected to the LMCs. Furthermore, there are no common citizen representatives in the LMCs (i.e., citizens without leadership status or representing a specific group).

The lack of clear local community representation in the LMCs can contribute to spending that does not reflect the most urgent development needs in the mining communities. As the

73 Crawford G, 'Making Democracy a Reality'? The Politics of Decentralisation and the Limits to Local Democracy in Ghana’ (2009) 27(1) Journal of Contemporary African Studies 58-59.

74 Grove K and Pugh J, 'Assemblage thinking and participatory development: Potentiality, ethics, Biopolitics (2015) 9(1) Geography Compass, 1-13; Thomas P (Ed), 'Introduction: Challenges for Participatory Development in Contemporary Development Practice' In Challenges for Participatory Development in Contemporary Development practice (Australia: The Development Studies Network 2013) 5.

75 Chambers R, 'Poverty and Livelihoods: Whose Reality Counts?' (1995) 7(1) Environment and Urbanization, 173-204; Grove and Pugh (n 74 above) 5; Reed MS 'Stakeholder Participation for Environmental Management: A Literature Review' (2008) 141(10) Biological Conservation 2417-2431 doi:https://doi.org/10.1016/j.biocon.2008.07.014.

76 Act 912, 19(2)(d-e) 9. 
members are mainly appointed or/and take their position in the committee by virtue of their position in society (e.g., chiefs), the MCDS scheme provides a limited arena for local community members' voices and needs to be heard and limits local participation. Given that, in Ghana, people are traditionally more accountable to the superiors who appointed them, and since they can lose their power if they disobey their superiors, it is likely that the LMC members will be upwardly accountable to the MDF board, which, in turn, will be accountable to the President. Consequently, the LMC members may not be downwardly accountable to the people they are supposed to represent.

In addition, the way in which LMC members are selected can, in the worst case, reinforce the power of existing elites. Experiences from Sierra Leone, where the Diamond Area Community Development Fund (DACDF) and the Chiefdom Development Committees (CDC) were established in 2001 to facilitate socio-economic development in diamond mining communities, which is similar to the MCDS scheme and LMCs in Ghana, suggest that appointing members to the LCMs may reinforce existing power structures. ${ }^{77}$ Although the CDCs were supposed to be 'composed of a wide cross-section of elected chiefdom residents', the paramount chiefs often appoint their close friends and relatives to the CDCs, which has led to limited local representation and participation and has resulted in cronyism and the misuse of revenues. ${ }^{78}$ As the structure of LMCs is very similar to that of CDCs, the Act may result in reinforcing existing power structures and patronage networks in Ghana.

\section{Royalty disbursement}

The Act fails to address the challenge related to delays in disbursing mineral royalties to the MDF and OASL. Although the companies regularly pay mineral royalties to the GRA, the Act does not stipulate when the MDF should receive its share nor how often and when the MDF should transfer royalties to the OASL. Unfortunately, the Act has no provisions mandating that the GRA transfer the 20 per cent of the mineral royalties directly to the MDF's account without the funds first going to the CF. Thus, the MoFEP is still the agency that disburses mineral royalties to the MDF, and it is under its discretion when and how often it chooses to do so.

77 Dupuy (n 9 above) 74-75; Maconachie R 'The Diamond Area Community Development Fund: Micropolitics and Community-Led Development in Post-War Sierra Leone' In P Lujala and SA Rustad (Eds.) High-Value Natural Resources and Post-Conflict Peacebuilding (London: Earthscan 2012) 266-267.

78 Maconachie (n 77 above) 267. 
Another issue is that the share of the mineral royalties designated to the MCDS scheme is most likely inadequate to support significant socio-economic development in the mining communities. Even if the royalties going to the district assemblies and the traditional councils were added to the MCDS scheme, the funds would still most likely be inadequate. The Ghana Chamber of Mines estimates that the mining communities need at least 30 per cent of total mineral royalties to be able to address their needs. ${ }^{79}$ This implies that the entire 20 per cent now going to the MDF would not be sufficient to address the mining-related challenges and development needs of the mining communities. Further, compared to other developing countries with extensive mining activities, the shares going to the mining communities in Ghana are modest. Ecuador, which also taxes 5 per cent of mineral revenues as royalties, transfers 60 per cent of such funds to local governments, and half of that (i.e., 30 per cent of total mineral royalties) is earmarked for mining community development. ${ }^{80}$ In Kenya, mining communities receive 5 per cent of total mineral revenues (i.e., the entire mineral royalty in Ghana) ${ }^{81}$ Thus, the MCDS scheme is likely to be underfunded to address the development needs of Ghana's mining communities.

\section{$\underline{\text { Transparency and accountability }}$}

Ghana has actively pursued transparency and accountability in its extractive sector management since it joined the Extractive Industries Transparency Initiative (EITI) in 2003, ${ }^{82}$ receiving international recognition for its commitment. ${ }^{83}$ Currently, the country makes information available on various aspects of its extractive sector, such as production volumes,

79 Ghana Chamber of Mines (n 44 above) 21.

80 Dupuy KE, 'Community Development Requirements in Mining Laws' (2014) 1(2) The Extractive Industries and Society 212 doi: https://doi.org/10.1016/j.exis.2014.04.007; Vallejo Galárraga MC and Freslon WS 'Ecuador: Mineral Policy' In G Tiess, T Majumder and P Cameron (Eds.) Encyclopedia of Mineral and Energy Policy (Berlin: Springer Berlin Heidelberg 2017) 6.

81 Dupuy (n 80 above) 214.

82 For a more detailed account of how the EITI came into existence, how it functions, and what its objectives are, see, for example, Haufler V, 'Disclosure as Governance: The Extractive Industries Transparency Initiative and Resource Management in the Developing World' (2010) 10(3) Global Environmental Politics 53-73 doi: https://doi.org/10.1162/GLEP_a_00014; Kasekende E, Abuka C and Sarr M, 'Extractive Industries and Corruption: Investigating the Effectiveness of Eiti as Scrutiny Mechanism' (2016) 48(C) Resources Policy 117-128 doi: http://dx.doi.org/10.1016/j.resourpol.2016.03.002; Rustad SA, Le Billon P and Lujala P, 'Has the Extractive Industries Transparency Initiative Been a Success? Identifying and Evaluating EITI Goals' (2017) 51 Resources Policy 151-162 doi: https://doi.org/10.1016/j.resourpol.2016.12.004.

83 For example, the 2016 Peru conference acknowledged Ghana as a Star Performer in using EITI to influence policy reforms in the EI sector. 
export data, and payments to the government and leaseholders, through annual EITI reports. ${ }^{84}$ Further, the 2011 Petroleum Revenue Management Act (PRMA) embedded strong transparency and accountability measures that require the disclosure of petroleum receipts, production volumes, and oil and gas prices on a quarterly basis and established the independent Public Interest and Accountability Committee (PIAC) to ensure compliance with the PRMA Act and facilitate citizens' capability and willingness to hold the government accountable for managing and spending petroleum revenues. ${ }^{85}$ Ghana thus mainstreamed several EITI principles in the PRMA Act.

It is therefore surprising that the MDF Act does not provide any specific stipulations for transparency and accountability beyond requiring the MDF board to 'ensure accountability of the moneys of the fund by defining appropriate procedures for accessing and monitoring the fund ${ }^{86}$ and requiring the minister responsible for mines, together with the MDF board, to prepare and publish the criteria for the 'disbursement and utilization of the moneys of the fund' in a national newspaper. ${ }^{87}$ Thus, there are no embedded mechanisms in the Act that require information disclosures regarding the royalties accruing to the MDF, the royalties that it transfers to other institutions and how these funds are spent. Further, an interview with an MDF official revealed that the Act does not mandate the OASL to audit the district assemblies and traditional authorities to which it transfers mineral royalties. Currently, the OASL must provide the MDF board only with a report on mineral royalty disbursement to district assemblies and paramount chiefs. ${ }^{88}$ Therefore, the MDF board is able to track only the disbursements made to the local authorities by the OASL and not how the royalties are spent.

There is a clear need and demand for increased information to be provided to local community members in Ghana regarding natural resource revenues accruing to local authorities and other institutions managing natural resource revenues on their behalf. ${ }^{89}$ Common citizens currently

84 The annual EITI Report is the core EITI product and contains data on each country's extractive industries in accordance with the EITI standards (see https://eiti.org/document/guidance-note-on-publishing-eiti-data).

85 Petroleum Revenue Management Act. Act 815 (see mofep.gov.gh/sites/default/files/acts/PetroleumRevenue-Management-ACT-815.pdf).

86 Act 912, 7(d).

87 Act 912, 7(e).

88 Interview with an MDF official, June 2018.

89 Lujala P, Brunnschweiler C and Edjekumhene I, 'Transparent for Whom? Dissemination of Information on Ghana's Petroleum and Mining Revenue Management' (2018) Munich Personal RePEc Archive (MPRA Paper 84788) 17; Kasimba S and Lujala P, 'There Is No One Amongst Us with Them! Transparency and Participation in Local Natural Resource Revenue Management' (2018) the Extractive Industries and Society, 198-205, doi: https://doi.org/10.1016/j.exis.2018.10.011; Ofori JJY and Lujala P, 'Illusionary Transparency? 
have little knowledge of how much revenue should be disbursed to their districts and communities and how these funds are spent, although many suspect their chiefs benefit unduly from such revenues. ${ }^{90}$ Therefore, the Act has missed an opportunity to firmly establish mechanisms and procedures for increased transparency and accountability in mineral royalty transfers, MDF, OASL, traditional authorities and district assemblies' royalty spending and MCDS funded projects.

\section{Emerging implementation issues}

Ghana has established an MDF secretariat in preparation for implementing the Act's provisions. The secretariat now faces three major challenges. First, there is no legislative instrument to operationalise the Act. ${ }^{91}$ Second, the establishment of the LMCs has been delayed. Third, the MDF has not yet received mineral royalties in a timely manner.

After the enactment of Act, it took the government three years to appoint the MDF board, which took place in April 2019. The delay in appointing the board has contributed to the lack of regulation to effectively implement the Act. For example, according to Section 26 of the Act, the MDF board is to advise the Minister for Land and Natural Resources on an LI to regulate and operationalise the Act. The Minister is now working on an LI to be approved by the Parliament.

Further, as the board is central in appointing the chairperson for the LMC, the LMCs are only now being established and have yet to be functional. Additionally, as the MDF board is responsible for reviewing, approving and financing the MCDS project proposals, development projects in the mining communities have been significantly delayed.

Another emerging implementation challenge is that the MDF does not receive the royalty disbursements on time. ${ }^{92}$ Although the mining companies pay mineral royalties to the $\mathrm{CF}$ through the GRA every month, ${ }^{93}$ the MoFEP, which manages the CF, releases the royalties to the MDF once every two or three months. ${ }^{94}$ Sometimes, the MoFEP fails to release mineral

Oil Revenues, Information Disclosure, and Transparency' (2015) 28(11) Society \& Natural Resources 1194 doi: https://doi.org/10.1080/08941920.2015.1024806

90 Lujala et al, (n 89 above); Kasimba and Lujala (n 89 above).

91 Legislative instruments are used in Ghana to interpret and operationalise Acts and Laws.

92 CEDA, A Review of the Minerals Development Fund Act, 2016 (Act 912), (Ghana: CEDA 2018) 14

93 The GRA informs all the relevant mining institutions and the Bank of Ghana about the amount of the mineral royalty received monthly through the MoFEP.

94 Interview with an MDF official, June 2018. 
royalties to the MDF for several months, which has resulted in considerable payment arrears. For the period of March 2016, when the Act was enacted, to the end of the 2017 fiscal year, the MoFEP still needed to release 97 million Cedis (US\$ 23 million) to the MDF in June 2018. ${ }^{95}$ In fact, for 2017 and up to October 2018, the MDF received less than half of its annual royalty allocation, that is, 8.5 per cent and 9.5 per cent respectively, of all mineral royalties collected. ${ }^{96}$ Thus, the chronic delays in royalty disbursements of the pre-Act time persist. Unless the arrears are paid and the MDF begins to receive the royalties on time, it will be difficult for the MDF to fund and sustain MCDS projects.

\section{Recommendations}

Based on the analysis, we conclude that the 2016 Minerals Development Fund Act in 2016 missed the opportunity to fully address many of the challenges in the allocation and utilisation of mineral royalties in Ghana. Based on the results, we make 5 recommendations.

1) Clarify how the royalties going to the traditional councils can be spent The linguistic ambiguity of Section 267(6) of the Constitution has led to the misuse of the 25 per cent mineral royalty assigned to the traditional councils as it has been interpreted by some traditional councils and paramount chiefs to mean that the mineral royalties can be used to fund consumption and the chiefs' personal projects instead of community development projects. Moreover, it is unclear to what extent these royalties should be spent to develop the mining communities. Although, ultimately, the Constitution's clause on how the use of the 25 percent revenue share going to the traditional authority 'for the maintenance of the stool in keeping with its status' should be clarified, the attorney general should without delay indicate for what the 25 per cent royalty share received by the traditional councils from the OASL should be used, and this clarification should be included in a legislative instrument.

2) Change the LMC composition and how the community members are selected To enhance local participation in the administration of the MCDS to encourage participatory development, the LMC should have more community member representatives, and they should be elected by community members. Currently, the

95 Ibid.

96 CEDA (n 92 above) 
LMC does not include any common citizens. In addition, the LMC could include representatives from recognised community groups other than only women's and youth group representatives such as local civil society organisations. In addition, the role of mining company representatives in the LMC should be clarified as the companies' interests may not always align with the interests of the local communities.

\section{3) Increase the MCDS share to 20 per cent of total mineral royalties}

To ensure that the mining communities receive sufficient funds for socio-economic development, the MCDS scheme should be assigned at least 20 per cent of the total mineral royalties paid by the mining companies (currently, the scheme's share is 4 per cent). This change could be achieved by increasing the royalty share going to the MDF from 20 per cent to 30 per cent and by reassigning some of the share going to the OASL to MCDS. This change would ensure more adequate funding for development projects in the mining communities and hinder the spending of royalties on a series of small development projects of limited benefit to the local people.

\section{4) GRA should disburse mineral royalties directly to the $M D F$}

The GRA should transfer the mineral royalties directly to the MDF to avoid delays and the non-payment of mineral royalties to local authorities and the MCDS scheme. The Act should be amended to stipulate that the GRA must transfer mineral royalties to the MDF for onward disbursement to the MCDS and other mining institutions every quarter as soon as it receives payments from mining companies.

\section{5) Publish information on royalty transfers and spending}

To enhance transparency and accountability, the MDF should publish, on a bi-annual basis, the amount of mineral royalties it has received, its royalty transfers to other institutions and its own royalty spending. Further, on an annual basis, the MDF and the OASL should publicise information regarding how much of the royalties should be received by the different local authorities and LMCs, how much they have received and how the royalties have been spent in the respective mining communities. 


\section{Conclusion}

In March 2016, Ghana's Parliament enacted the MDF Act (Act 912) to provide financial resources to the mining communities and mining-related institutions. The Act became necessary as the pre-Act MDF was managed by administrative directives, and the mining communities were not developing as they should have. The Act, therefore, provides legal backing for the MDF and seeks to ensure that the mining communities receive their fair share of the mineral royalties to support their socio-economic development.

This article provides five key findings. First, the Act has not addressed the fundamental linguistic ambiguity that makes possible mineral royalty misappropriation and misuse by traditional authorities. In addition, the Act does not provide tools for addressing the misuse of mineral royalties by district assemblies. Second, the composition and method used to appoint members to the LMCs lead to local disenfranchisement and discourage the participation of local community members in decision making concerning mineral royalty spending. Third, the Act fails to address delays in disbursing mineral royalties to the MDF, leading to significant arrears. Fourth, the percentage of mineral royalties assigned to the MCDS is inadequate to effectively address the negative effects of mining and to support development in the mining communities. Finally, the Act has limited mechanisms to ensure transparency and accountability in the spending of mineral royalties by the MDF and local authorities and in the use of disbursements made according to the MCDS scheme. 
Table 1: Disbursement of mineral royalties by the MDF

\begin{tabular}{|c|c|c|}
\hline Share & Responsible Body & Purpose \\
\hline $50 \%$ & $\begin{array}{l}\text { The Office of the Administrator of } \\
\text { Stool Lands (OASL) }\end{array}$ & $\begin{array}{l}\text { To provide financial resources to the } \\
\text { mining communities and authorities of the } \\
\text { traditional areas and districts within which } \\
\text { the mining communities are located }\end{array}$ \\
\hline $20 \%$ & $\begin{array}{l}\text { The Mining Community } \\
\text { Development Scheme (MCDS) }\end{array}$ & To develop the mining communities \\
\hline $4 \%$ & $\begin{array}{l}\text { The Ministry of Lands and Natural } \\
\text { Resources (MLNR) }\end{array}$ & \multirow{3}{*}{$\begin{array}{l}\text { To promote and support the research and } \\
\text { development of the mining sector }\end{array}$} \\
\hline $13 \%$ & The Minerals Commission & \\
\hline $8 \%$ & $\begin{array}{l}\text { The Geological Survey } \\
\text { Department (GSD) }\end{array}$ & \\
\hline $5 \%$ & $\begin{array}{l}\text { The Minerals Development Fund } \\
\text { (MDF) }\end{array}$ & $\begin{array}{l}\text { For mining-related research and training } \\
\text { and projects promoting sustainable } \\
\text { development; at least } 40 \text { per cent of this } \\
\text { share must go to the GSD }\end{array}$ \\
\hline
\end{tabular}

${ }^{I}$ The GSD is a statutory body responsible for collecting, generating, disseminating, storing and archiving geoscientific data.

Source: Based on Act 912, 21. 


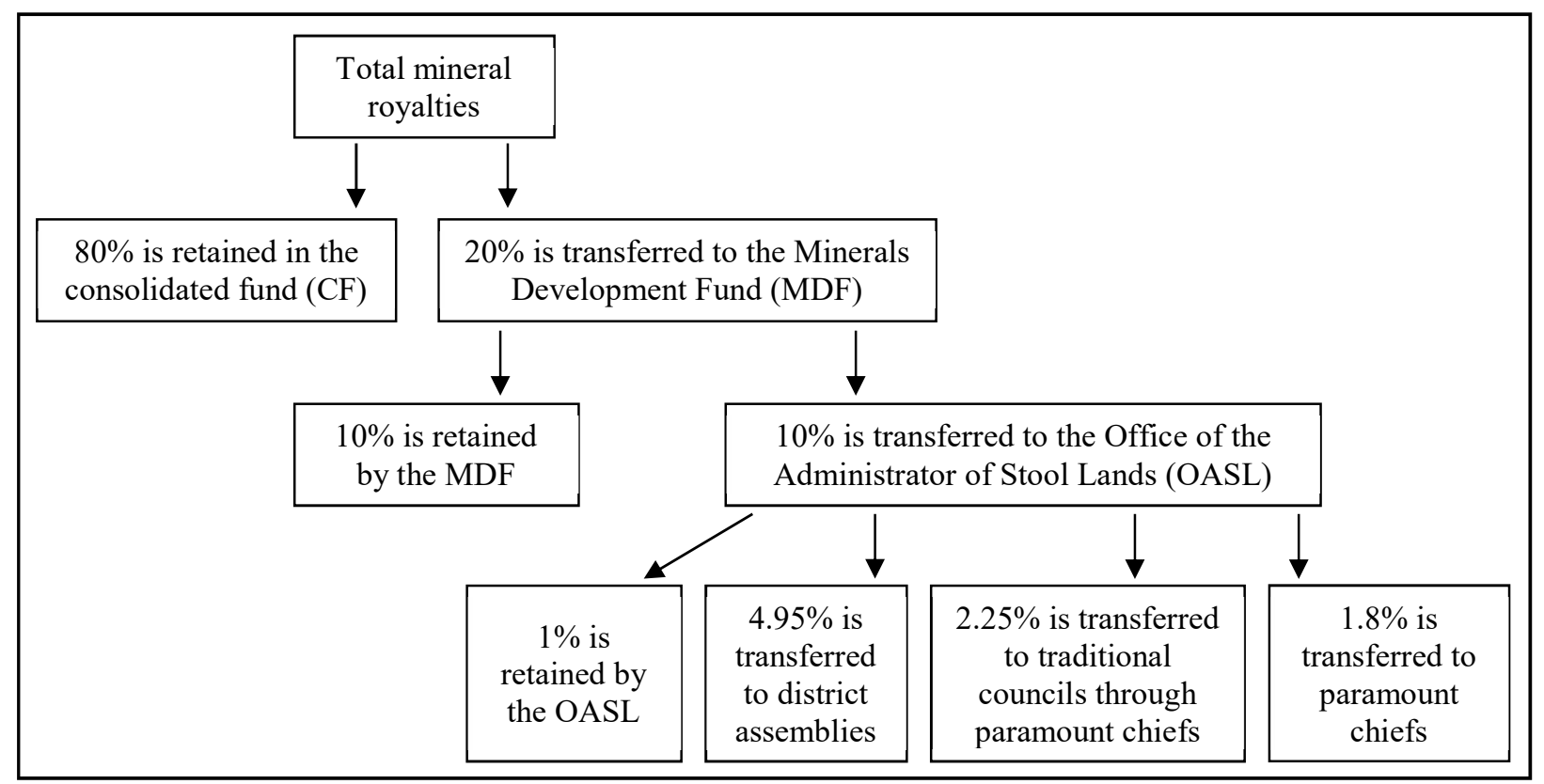

Figure 1: Ghana's mineral royalty distribution scheme 